\title{
A Comparative Study of Staphylococcus aureus Strains Isolated from Bovine Subclinical Mastitis During 1952-1956 and 1992
}

\author{
By F. M. Aarestrup ${ }^{1}$, H.C. Wegener ${ }^{1}$ and V.T. Rosdahl ${ }^{2}$ \\ ${ }^{1}$ Danısh Veterinary Laboratory and ${ }^{2}$ Statens Serumınstitut, Copenhagen, Denmark.
}

\begin{abstract}
Aarestrup, F.M., H.C. Wegener and V.T. Rosdahl: A comparative study of Staphylococcus aureus strains isolated from bovine subclinical mastitis during 1952-1956 and 1992. Acta vet. scand. 1995, 36, 237-243. - Fiftytwo strains of $S$ aureus isolated from cases of bovine subclinical mastitis in 52 different dairy herds in Denmark, in the per1ods 1952 to 1956 and 1992, were compared with regard to their phage- and EcoRI ribotypes. Furthermore, susceptibility to penicillin and production of fibrinolysin were used as additional phenotypic markers. Fortynine strains (94\%) could be separated into 12 phage types. Ribotyping assigned the 52 strains to 21 different types. Both methods showed that $57 \%$ of the 1950 's strains and between $38-45 \%$ of the 1992 strains belonged to 3 domınatıng types. The remaining strains were placed by ribotyping in 8 types occurring among the 1952-1956 strains and 10 types occurring among the 1992 strains. In $87 \%$ of the strains the results of the 2 typing methods were in accordance. However, 7 strains gave different results by the 2 methods including 2 strains with major differences. Penicillin resistance only occurred in a single genotype from the 1950's compared to 6 different genotypes among the 1992 strains.
\end{abstract}

phage typing; ribotyping.

\section{Introduction}

Mastitis, an inflammation of the mammary gland, usually caused by bacterial infection is the most economically important disease in dairy cattle (Anon 1987). Attempts, over the years, to eradicate mastitis has resulted in a shift in the prevalence of the causative bacteria (Booth 1988, Dodd 1985, Schalm et al. 1971, Bramley \& Dodd 1984). Thus, during the last 40 years Streptococcus agalactiae has become less prevalent while Staphylococcus aureus is more common, and is now the most prevalent mastitis pathogen in Denmark (Anon 1985, Rømer 1949). Phage typing has proved useful in differentiating strains of $S$. aureus from bovine mastitis (Davidson 1972,
Holmberg 1975, Mackie et al. 1987), and has been used for epidemiological investigations in dairy herds (Davıdson 1961, Fox et al. 1991, Mackie et al. Price et al. 1954). A change over time in the phage type patterns of $S$. aureus of human origin has been observed, together with an increase in penicillin resistance (Zierdt et al. 1980, Renneberg \& Rosdahl 1992). Ribotyping has been used in epidemiological studies of $S$. aureus from human sources (Blumberg et al. 1992). This paper reports a comparison of phage typing and ribotyping of $S$. aureus isolated from bovine mastitis during the years 1952-1956 and 1992, in order to investigate a possible change in $S$. aureus types during the last 40 years. 


\section{Materials and methods}

Twenty three strains of $S$. aureus isolated from 1952-1956 and 29 isolated during 1992 were investigated. All were from different farms. The lyophilized cultures from 1952-1956 were suspended in nutrient broth no. 2 (Oxoid) and subcultured on bovine blood agar (Columbia agar, CM 331, supplemented with 5\% sterile lysed bovine blood). The strains from 1992 derived from aseptically taken milk samples, which were inoculated directly on bovine blood agar.

The strains were phage typed (Blair \& Williams 1961) using the international set of typing phages for human strains (Parker 1983), and fibrinolysin production assayed (Devriese \& Van De Kerckhove 1980).

A tablet diffusion method (Casals \& Pringler 1991) on DST-agar (Oxoid CM261) using Neo-Sensitabs (5 mg) (Rosco Diagnostica, Taastrup, Denmark), was used to determine the sensitivity to penicillin.

For ribotyping, bacterial DNA was obtained by a modification of the method described by Ausubel et al. (1989). In brief, bacterial strains were grown overnight in trypticase soy broth, supplemented with $10 \mathrm{~g}$ yeast extract per litre and $1.5 \mathrm{ml}$ of the overnight culture was centrifuged. The bacterial precipitate was dispensed in $567 \mu \mathrm{l}$ TE $(10 \mathrm{mM}$ Tris, $1 \mathrm{mM}$ EDTA), $125 \mathrm{U}$ of lysostaphin (Sigma, St. Louis, USA) was added, and bacterial cells were lysed during an incubation period of $1 \mathrm{~h}$ at $37^{\circ} \mathrm{C}$. Subsequently, $30 \mu \mathrm{l}$ of Sodium dodecyl sulfate $(10 \%)$, and $6 \mu \mathrm{l}$ proteinase $\mathrm{K}$ (Merck, Darmstadt, Germany) $(10 \mathrm{mg} / \mathrm{ml})$ was added, followed by incubation at $37^{\circ} \mathrm{C}$ for $1 \mathrm{~h}$. Cell wall debris, polysaccharides and remaining proteins were precipitated by addition of hexadecyl-trimethylammonium-bromide (Fluka Chemie AG, Buchs, Switzer-land) $(10 \% \mathrm{w} / \mathrm{v}$ in $0.7 \mathrm{M} \mathrm{NaCl})$, and DNA was purified by extraction with chloro- form/isoamylalcohol (24:1) and subsequently, with phenol/chloroform/isoamylalcohol (25:24:1). Ribosomal DNA patterns were obtained by digesting total DNA (2-6 $\mu \mathrm{g})$ with 2 units of EcoRI (Amersham, Arlington Heights, IL, USA) for $18 \mathrm{~h}$ and the fragments were separated by electrophoresis $(30 \mathrm{~V}, 18 \mathrm{~h})$ in a $0.8 \%$ agarose gel. DNA fragments were transferred onto a Hybond-N membrane (Amersham, Arlington Heights, IL, USA) as described by Southern (1975). Filters were hybridized with digoxiginin labelled cDNA probe reversely transcribed from Escherichia coli $16 \mathrm{~S}$ and $23 \mathrm{~S}$ rRNA (Boehringer, Mannheim, Germany), according to the manufacturer's recommendations. Filters were developed using a commercial digoxigenin staining kit, according to the manufacturer's descriptions (Boehringer, Mannheim, Germany).

\section{Results}

Phage typing assigned 49 of the 52 strains to 12 different types, 3 strains were nontypable (Table 1). Three types (A, B and C) comprised $65 \%$ and $48 \%$ of the strains from 1952 1956 and 1992, respectively. Type D and E occurred with a frequency of $34 \%$ among the 1992 strains but accounted for only 1 strain from 1952-1956. Four types were represented among the 1952-1956 strains and 3 among the 1992 strains. Ribotyping subdivided the 52 strains into 21 types (Table 2), with 3 types (1, 2 and 3 ) accounting for $65 \%$ and $45 \%$ of the 1952-1956 and 1992 strains, respectively. Type 13 and 14 occurred with a frequency of $24 \%$ among the 1992 strains and none among the 1952-1956 strains. Ribotyping subdivided the strains into more types than phage typing (Table 2). Strains of phage type A (3A/3C) belonged to ribotype 3, except one 1952-1956 strain that belonged to ribotype 11 . Among the phage type B strains (77) all the 7 1952-56 
Table 1: Phage types among strains of $S$. aureus isolated from bovine subclinical mastıtis during 1952-1956 and 1992.

\begin{tabular}{|c|c|c|c|c|}
\hline $\begin{array}{l}\text { Type } \\
\text { label }\end{array}$ & Phage type & $\begin{array}{c}\text { Phage type } \\
\text { pattern }\end{array}$ & $\begin{array}{c}\text { No. of strains } \\
\text { recovered } \\
\text { during 1952- } \\
1956\end{array}$ & $\begin{array}{c}\text { No of strains } \\
\text { recovered } \\
\text { during } 1992\end{array}$ \\
\hline
\end{tabular}

\begin{tabular}{llccc}
\hline A & $3 \mathrm{~A} / 3 \mathrm{C}$ & II & 3 & 6 \\
B & 77 & III & 7 & 5 \\
C & $29 / 52 / 52 \mathrm{~A} / 80 / 85$ & Mix & 5 & 3 \\
D & $47 / 75$ & III & 1 & 4 \\
E & $29 / 52$ & I & & 6 \\
F & 54 & III & 1 & 1 \\
G & $53 / 85$ & III & 2 & \\
H & $6 / 53 / 75 / 93 / 89$ & III & 1 & \\
I & 79 & I & 1 & \\
J & $52 / 52 A / 80$ & I & 1 & 1 \\
K & $29 / 47 / 53 / 85 / 93 / 89$ & Mix & & 1 \\
L & $29 / 52 / 6 / 42 E / 47 / 84 / 85$ & Mix & & 2 \\
& non typable & & 1 & 29 \\
\hline
\end{tabular}

Each letter refers to a phage type as represented in Table 2. Numbers represent the numbers of each phage type found among each group of bacterial strains.

strains belonged to ribotype 1 as well as 3 of the 1992 strains, but 2 of the 1992 strains belonged to 2 other ribotypes (12 and 15). Strains of phage type C (29/52/52A/80/85) belonged to ribotype 2 except 1 of type 7 (19521956) and 1 of type 21 (1992). Seven strains were placed in the same ribotype although they belonged to different phage types. Among the 12 strains belonging to ribotype 1, ten were of phage type 77 , while 1 was of the quite distinct phage type $29 / 52$. In ribotype 3 , 8 strains belonged to phage type $3 \mathrm{~A} / 3 \mathrm{C}$ and 1 to a quite different phage type $29 / 47 / 53 / 85 / 93 / 89$. The remaining strains were placed in ribotypes together with strains of related phage types (B with $\mathrm{D}, \mathrm{F}$ with $\mathrm{D}, \mathrm{L}$ with $\mathrm{E}$ and $\mathrm{C}$ with $\mathrm{E}$ ).

Resistance to penicillin was observed in five 1952-1956 strains (22\%) and nine 1992 strains (31\%). Among the 1952-1956 strains, only strains of ribotype 1 and phage type 77 (B) were found to be resistant towards penicillin. In contrast, penicillin resistance was found in 6 different ribotypes and 6 different phage types among the 1992 strains (Table 2).

Production of fibrinolysin was observed in seven 1952-1956 strains (30\%) and four 1992 strains (14\%) (Table 2).

\section{Discussion}

De Buyser et al. (1992) found that ribotyping was useful as a marker of phylogenetic relatedness among different strains within Staphylococcus species. Furthermore, ribotyping has shown good discriminatory power within single species, making it useful for epidemiological investigations of $S$. aureus of human origin (Blumberg et al. 1992).

Subtyping of $S$. aureus from cattle has mainly concerned phage typing. Many phage types are associated with bovine mastitis although 
Table 2: Phage- and ribotypes of strains of $S$. aureus isolated from bovine subclinical mastitis durıng 1952-1956 and 1992.

\begin{tabular}{|c|c|c|}
\hline ribotype & $\begin{array}{l}\text { Strains recovered } \\
\text { durnng 1952-1956 }\end{array}$ & $\begin{array}{l}\text { Strains recovered } \\
\text { durıng } 1992\end{array}$ \\
\hline 1 & $\mathrm{~B}^{1} \mathrm{~B}^{1} \mathrm{~B}^{1} \mathrm{~B}^{1} \mathrm{~B}^{1,2} \mathrm{~B}^{2} \mathrm{D}$ & $\mathrm{B} \mathrm{B} \mathrm{B}^{2} \mathrm{E}^{1}$ \\
\hline 2 & $\mathrm{CCC} \mathrm{Cnt^{2) }}$ & $\mathrm{C} \mathrm{C}^{1}$ \\
\hline 3 & A A & A A A A A $\mathrm{A}^{1} \mathrm{~K}^{1}$ \\
\hline 4 & $\mathrm{H}^{2}$ & \\
\hline 5 & $\mathrm{~F}^{2}$ & \\
\hline 6 & $\mathrm{I}^{2}$ & \\
\hline 7 & $\mathrm{C}$ & \\
\hline 8 & $\mathrm{G}$ & \\
\hline 9 & G & \\
\hline 10 & $\mathrm{~J}^{2}$ & \\
\hline 11 & A & \\
\hline 12 & & B \\
\hline 13 & & F D D ${ }^{2}$ \\
\hline 14 & & $\mathrm{E} \mathrm{E}^{1} \mathrm{E}^{1} \mathrm{~L}^{1}$ \\
\hline 15 & & B \\
\hline 16 & & $\mathrm{nt}$ \\
\hline 17 & & $\mathrm{E}$ \\
\hline 18 & & $\mathrm{nt}$ \\
\hline 19 & & $C E^{1}$ \\
\hline 20 & & $\mathrm{D}^{1}$ \\
\hline 21 & & $\mathrm{D}^{2}$ \\
\hline
\end{tabular}

Numerals represent different ribotypes. Letters refer to a phage type of 1 strain. The corresponding phage pattern can be seen from Table 1 . $\mathrm{nt}=$ non typable, $1=$ resistance to penicillin, $2=$ production of fibrinolysin.

only some predominate (Smith 1948, Fox et al. 1991, Mackie et al. 1987, Price et al. 1954). The comparison of phage typing results between different authors is difficult because of the use of different phages, different concentrations of the typing phages, and different criteria for discrimination between strains of different phage types.

In this study $2 S$. aureus collections from cases of bovine mastitis in 1952-1956 and 1992 have been compared. Although the material is relatively small some general patterns are observed. When comparing the 1952-1956 and 1992 strains it appeared that the 3 most common phage types among the 1952-1956 strains were also prevalent among the 1992 strains, whereas the rare types differed. However, phage types 29/52 and 47/75, which accounted for $34 \%$ of the 1992 strains, only accounted for 1 strain among the 1952-1956 strains. This might indicate that some new phage types have emerged and established themselves successfully during the last 40 years. Ribotyping subdivided strains of the same phage type and might be a valuable tool in solving epidemiological problems when only a few phage types predominate. As for phage typing it appeared that the 3 most common ribotypes among the 1952-1956 strains were prevalent among the 1992 strains, whereas a shift occurred in the prevalence of other types. Ribotype 13 and 14 appeared to have increased during the last 40 years and accounted for $24 \%$ of the 1992 strains. 


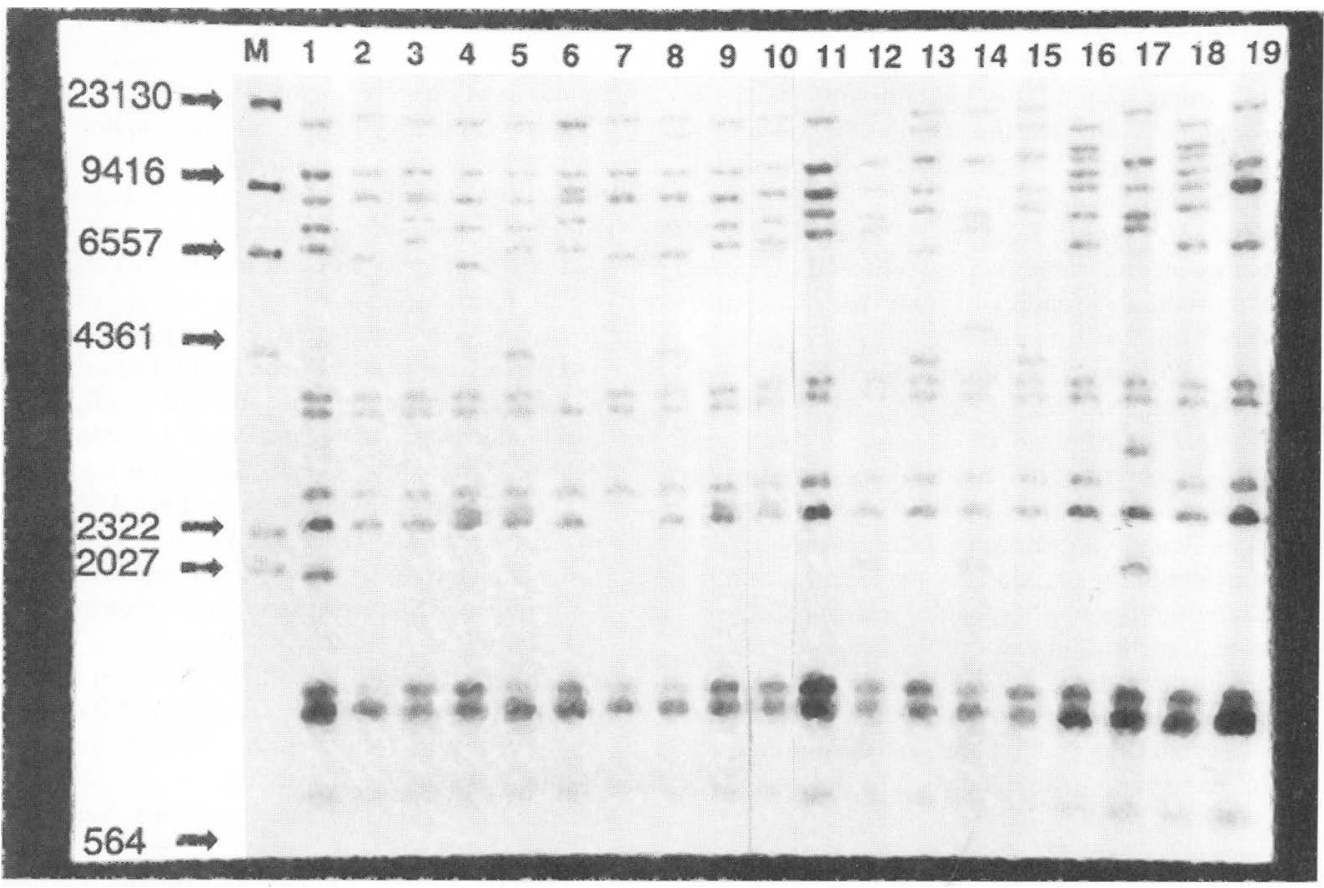

Figure 1. Representative EcoRI restriction fragment length polymorphisms of the gene encoding ribosomal RNA (ribotypes) of Staphylococcus aureus strains isolated from bovine subclinical mastitis during 1952-1956 (23 strains) and 1992 (29 strains). Numbers as in Table 2 Marker: HindIII digested Lambda-DNA.

Penicillin resistance was found in five 19521956 strains, all of which belonged to ribotype 1 and phage type B (Table 2). Penicillin has been used commonly to treat mastitis in dairy herds and this may account for penicillin resistance being present in 6 ribotypes and 6 phage types among the 1992 strains.

Fibrinolysin production was detected among most of the ribotypes of both the 1952-1956 and 1992 strains.

In conclusion, ribotyping was useful in classifying strains of $S$. aureus from subclinical bovine mastitis. Phenotypic markers such as phage typing, penicillin resistance and fibrinolysin production could be used to further subdivide individual genotypes, making them useful as epidemiological markers. It is, how- ever, noteworthy that 2 strains of distinctly different phage types are placed together by ribotyping. This observation underlines the importance of combining 2 or several typing methods.

\section{Acknowledgement}

We gratefully acknowledge the assistance of René Hendriksen and the staff of the Department of Microbiology. We are grateful to N.O. Klastrup $\dagger$, DVM, for makıng the collection of the 1952-1956 strains available, to Johannes Jensen, DVM, for help in collecting the 1992 strains and to Niels Einar Jensen, DVM, for assistance in preparing the research and the manuscript.

† Deceased March 1994 


\section{References}

Anonymous: Progress in mastitis control. Bull. no. 187. International Dairy Federation 1985.

Anonymous: Bovine mastitis. Definition and guidelines for diagnosis. Bull. no. 211. International Dairy Federation 1987.

Ausubel FM, Brent R, Kingston RE et al: Short protocols in molecular biology, (2nd ed) Greene Publishing Associates and John Wiley and Sons, New York. 1989, pp 2-11.

Blair JW, Williams REO: Phagetyping of Staphylococci. Bull. Wld. Hlth. Org., 1961, 24, 771-784.

Blumberg HM, Rimland D, Klehlbauch JA, Terry $P M$, Wachsmuth IK: Epidemiologic typing of Staphylococcus aureus by DNA restriction fragment length polymorphisms of rRNA genes: Elucidation of the clonal nature of a group of bacteriophage-non typeable, c1profloxacin-resistant, methicillin-susceptible S.aureus isolates. J. Clin. Microbiol., 1992, 30, 362-369.

Booth JM: Update on mastitis: I. Control measures in England and Wales. How have they influenced incidence and aetiology? Br. Vet. J., 1988, 144, 316-322.

Bramley AJ, Dodd FH: Reviews of the progress of dairy science: Mastitis control - progress and prospects. J. Dairy Res., 1984, 51, 481-512.

Casals JB, Pringler N: Antibacterial sensitivity testing using Neo-Sensitabs. Rosco Diagnostica: Taastrup, Denmark, 1991.

Davidson I: Observations on the pathogenic Staphylococci in a dairy herd during a period of six years. Res. vet. Sci., 1961, 2, 22-40.

Davidson I: A collaborative investigation of phages for typing bovine Staphylococci. Bull. Wld. Hith. Org., 1972, 46, 81-98.

De Buyser ML, Morvan A, Aubert S, Dilasser F, El Solh $N$ : Evaluation of a ribosomal RNA gene probe for the identification of species and subspecies within the genus Staphylococcus. J. Gen. Microbiol., 1992, 138, 889-899.

Devriese LA, Van De Kerckhove A: A comparison of methods used for testing staphylokinase (fibrinolysin) produktion in Staphylococcus strains. Antonie van Leeuwenhoek 1980, 46, 457-465.

Dodd FH: Progress in mastitis control. Kieler Milchwirtschaftliche Forschungsberichte 1985, 37, 216-223.

Fox LK, Gershman M, Hanock DD, Hutton CT: Fomites and reservoirs of Staphylococcus aureus causing intramammary infections as determined by phage typing: the effect of milking time hygiene practices. Cornell Vet., 1991, 81, 183193.

Holmberg O: Phagetyping of Staphylococcus aureus strains isolated in Sweden from bovine milk. Acta vet. scand., 1975, 16, 411-419.

Mackie DP, Pollock DA, Rodgers SP, Logan EF: Phage typing of Staphylococcus aureus associated with subclinical bovine mastitis. J. Dairy Res., 1987, 54, 1-5.

Parker MT: The significance of phage-typing patterns in Staphylococcus aureus. In: Easmon CSF, Adlam C (eds): Staphylococci and Staphylococcal infections. Academic Press, London, New York, Paris, San Diego, San Francisco, Sao Paulo, Sydney, Tokyo, Toronto. 1983; 33-62.

Price P, Neave FK, Rippon JE, Williams REO: The use of phage typing and penicillin sensitivity tests in studies of Staphylococc from bovine mastitıs. J. Dairy Res., 1954, 21, 342-353.

Renneberg J, Rosdahl VT: Epidemılogical studies of penicillin resistance in Danish Staphylococcus aureus strains in the period 1977-1990. Scand. J. Infect. Dis., 1992, 24, 401-409.

Rømer O: Problems of mastitis. Nord. Vet.Med., 1949, 1, 509-527.

Schalm OW, Carroll EJ, Jain NC: Bovine mastitis. Lea and Febiger, Philadelphia. 1971.

Smith HW: The typing of Staphylococci of animal origin by the bacteriophage method. J. Comp. Pathol., 1948, 58, 179-188.

Southern EM: Detection of specific sequences among DNA fragments separated by gel electrophoresis. J. Mol. Biol., 1975, 98, 503-517.

Zierdt CH, Robertson EA, Williams RL, MacLowry $J D$. Computer analysis of Staphylococcus aureus phage typing data from 1957 to 1975, citing epidemiological trends and natural evolution within the phage typing system. Appl. Environ. Microbiol., 1980, 623-629.

\section{Sammendrag}

Sammenlignende unders $\phi g e l s e$ af Staphylococcus aureus stammer isoleret fra bovin subklinisk mastitis $\imath$ 1952-1956 og 1992

Tooghalvtreds stammer af Staphylococcus aureus isoleret fra bovin subklinisk mastitis, $i$ henholdsvis 1952-1956 og i 1992, blev sammenlignet med hensyn til deres fagtype og EcoRI ribotype, samt resistens overfor penicillin og produktion af fibrinolysin. Niogfyrre (94\%) af stammerne kunne henføres til 12 
forskellige fagtyper. Ribotypning henførte de 52 stammer til 21 forskellige typer. Begge metoder henførte $57 \%$ af 1952-1956 stammerne og mellem $38-45 \%$ af 1992 stammerne til 3 dominerende typer. De resterende typer fordelte sig på 8 ribotyper som kun forekom blandt 1952-1956 stammerne og 10 typer som kun forekom blandt 1992 stammerne. For
$87 \%$ af stammerne gav de 2 typningsmetoder overensstemmende resultater, mens de for 7 stammer gav afvigende resultater. Penicillin-resistens forekom kun 1 en genotype blandt stammerne fra 1950erne i modsætning til 6 forskellige genotyper blandt stammerne fra 1992.

(Received September 28, 1994; accepted February 9, 1995).

Reprints may be obtained from: F. M. Aarestrup, Danish Veterınary Laboratory, 27 Bülowsvej, DK-1790 Copenhagen V, Denmark. 
